\title{
The Accountant Perceptions of The IFRS Convergence Plan In Indonesia
}

\author{
Ersa Tri Wahyuni \\ Fakultas Ekonomi Universitas Padjadjaran Bandung \\ Jl. Dipati Ukur No. 35 Bandung 40132 \\ Email:ersatw@yahoo.com
}

\begin{abstract}
The Indonesian Institute of Accountants (Ikatan Akuntan Indonesia or IAI), on 23 December 2008, announced that the convergence of local standard to the international accounting standard (IFRS) should be completed by 2012. Indonesia as one of member of the Group of Twenty $(G-20)$ should strive to achieve IFRS compliance as it is one of $G-20$ goal and commitment in enhancing economic cooperation around the world. This study aims to examine Indonesian accountant perceptions regarding IFRS convergence in 2012.

This study is based on a survey which focuses on accountant perceptions in Indonesia. The total population in this study was 275 accountants and auditors who attended the four accounting events in Jakarta held by IAI and IAPI. There was a total sample of 143 respondents, 76 accountants from companies and 67 auditors from public accounting firms.

The research revealed many interesting findings. Overall the perception toward the IFRS convergence is positive with $72 \%$ respondents has a positive perception and $6.3 \%$ respondents have strong positive perception. Language issue in understanding PSAK (a translation from IFRS) is perceived as a problem more to the accountants work in companies rather than accounting firms. However both types of accountants view IFRS training to staffs as an important issue for IFRS implementation in Indonesia. With regard to the advantages of IFRS implementation in Indonesia, the foreign-affiliated institutions voiced higher agreement that IFRS will result in greater comparability of financial performance. They are also confident that Indonesia is ready for IFRS convergence by 2012 in contrast with non-affiliated institutions. And lastly accountants with $O^{-}$ 5 years experience group expressed greater concerns towards Indonesia's readiness for IFRS implementation as compared to accountants with more than 15 years experience. However overall perception shows that accounting professionals surveyed has positive perceptions towards IFRS convergence in Indonesia
\end{abstract}

Keywords: IFRS Convergence, Implementation, Accountants perception

\section{Background}

The Indonesian Institute of Accountants (Ikatan Akuntan Indonesia or IAI), on 23 December 2008, announced that the convergence of local standard to the international accounting standard (IFRS) should be completed by 2012. At 1 January 2012 it is expected that Indonesian Accounting Standard will be fully converged with IFRS as of 1 January 2009. Even though the decision of IFRS convergence has been decided in 2008, the pressure is increasing as Indonesia become the only South East Asian Countries in G20 Forum. Compliance with IFRS is one of commitment of G20 with the target mid-year 2011.

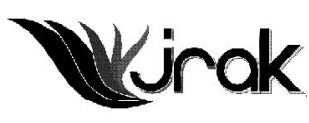

Jurnal Reviu Akuntansi dan Keuangan

ISSN: 2088-0685 Vol.1 No. 2, Oktober 2011 Pp 85-96 
The Accountant Perceptions ...

It is without surprise that the Indonesian Institute of Accountants faces resistance among accounting profession to the convergence plan especially in 2008 and 2009. However, as the Government and the market supervisory agency fully supported IIA decision, more and more accountants in Indonesia accept the fact that IFRS convergence is just a matter of time. The Accounting profession in Indonesia is quite young compare to other country with many challenges such as inadequate number of public accountant and serious aging problems; it would be very interesting to explore the perceptions of accounting professionals towards IFRS convergence in Indonesia. Especially the IFRS convergence may burden the profession by more rigorous fair value measurement and extensive use of professional judgment.

Ultimately, financial reporting users in Indonesia should be fully-prepared for making this IFRS convergence successful by 2012. Indonesia provides an interesting research setting as the change from rule based accounting standard to the principle based accounting standard was a sudden change compared to Malaysia and Singapore who also targeted 2012 as their year of IFRS adoption. Malaysia and Singapore have been harmonising their accounting standards to IFRS since many years ago, while Indonesia was very much based adopting the US Accounting standards until a major changing in 2008. This rapid change raises people's concern on the readiness of the accounting profession for IFRS adoption.

This study aims to examine Indonesian accounting professionals' perceptions regarding IFRS convergence in 2012. The research would investigate the accounting professionals' perceptions towards mandatory IFRS implementation. The scope of this research is limited to the perceptions of accountants from companies and the perceptions of public accountants from public accounting firms in Indonesia ${ }^{1}$.

\section{Literature Review}

Over the last decade, International accounting harmonisation and convergence with the increasing adoption of IFRS as national standards have become dominant topics in international accounting research (Asbaugh and Pincus 2001; Daske 2006; Daske and Gebhardt 2006; Othman and Zeghal 2006; Christensen et al. 2007; Ding et al. 2007; Haverals 2007; Tyrral et al. 2007; Daske et.al.2008; Lantto and Sahlstrom 2008).

After the first wave of global IFRS adoption in 2005, many research have been conducted mostly at the European jurisdiction. Armstrong, et.al (2008), in their study suggest that IFRS adoption brought convergence benefits to investors in $\mathrm{Eu}^{-}$ ropean firms such as greater comparability of firms' financial position. Investors in European firms belive that the expected benefits of IFRS adoption exceeded the expected costs. In sum, there are a number of studies suggesting that IFRS adoption provides substantial benefits to the all users of financial reporting (Jermakowixz, 2004; Gassen \&Sellhorn,2006; Ball 2006).

Daske, Hail, Leuz and Verdi (2008) found that market liquidity increases for firms that adopt IFRS reporting when it becomes mandatory. A decrease in firm's cost of capital and an increase in equity valuations occurred prior to IFRS official adoption date. Daske, Hail, Leuz (2007) also confirms that the decrease cost of capital is signicant only to the serious IFRS adopter compare to IFRS adopter only for label.

Armstrong, Barth, Jagolinzer and Riedl (2008), in their study also suggest that IFRS adoption brought convergence benefits to investors in European firms such as greater comparability of firms' financial position. Investors in European firms belived that the expected benefits of IFRS adoption exceeded the expected co sts.In sum, there are a number of studies suggesting that IFRS adoption provides substantial benefits to the all users of financial reporting (Jermakowixz E.K.2004; Gassen,J\&Sellhorn,T.2006; Ball R. 2006).

To avoid confusion, authors will refers to 'accountants from companies' as 'accountants' and 'public accountants from public accounting firms' as 'auditors'. The word "Accounting Professionals" refers to the all respondents, both accountants from companies and auditing firm. 
However as suggested by Bruggemann et al.( 2010), most of IFRS literature provide evidence positive reactions in capital markets and at the macroeconomic level using aggregrate commercial databases. Such databases may suffers from a systematic bias towards large companies. Empirical literature is still very limited on the economics consequences of IFRS mandatory adoption to the company's business decision.

Although the study on IFRS implementation is abundant in the European setting, the IFRS study in Asia is very limited. This mainly because Europe has already adopted IFRS as of 2005 while most countries in Asia will adopt IFRS in 2011 or 2012. The research on capital market reaction from IFRS adoption in Asia is scarce. Some study on disclosure regime after IFRS or IFRS adopted local standard are available in Malaysia (Carlin, Finch, Laili, 2008) and also the comparison study of market value versus book value after Malasyain FRS (Kadri and Mohammed, 2008)

A study on the mandatory application of IFRS is also availabe in Japan by Jun \& Koga (2009). The research examined the Japanese managers' negative attitude towards IFRS adoption possibly because they thought IFRS application would be difficult. Japan is only going to mandate IFRS for all companies in 2014 while voluntary adoption is open in 2010.

P.L.Joshi, G.Bremser, \& Al-Ajmi (2007) surveyed listed companies accountants and auditors in Bahrain asking them about their perceptions in the adoption and implementation of a single set of global accounting standards, IFRS. The respondents view optimism by that harmonization of accounting is a worthwhile objective that can be fairly, but gradually accomplished. Although challenges such as training and audit quality-control procedures emerged in IFRS adoption, the respondents viewed IFRS global adoption would bring benefits at the international level and would outweigh the costs.

PL.Joshi and S.Ramadhan (2002), in their study on IFRS adoption by small and closely held companies, found that ' $86 \%$ (31) of the 36 companies responding to the questionnaire applied IFRS and they considered IFRS to be very relevant for them'. The study aimed to examined the attitudes of professional accountants working in small and closely held companies towards the adoption of IFRS in Bahrain. The primary influence on the decision to adopt IFRS were the external auditors, banks and management. The respondents did not find IFRS adoption was costly or they faced any problems in applying IFRS. There were few firms that experienced some problems in interpreting the standards sought clarification from their external auditors. This study revealed that external auditors exerted the greatest influence on getting firms to adopt IFRS.

In Indonesia the research on IFRS is still very limited, Marlim (2009) conducted a research on measuring the level of conformity between SAK (Indonesian GAAP) as of 1 January 2008 with IFRS as of 1 January 2008. The study tested forty three accounting standards existed in SAK and IFRS as of 1 January 2008, and $75 \%$ of the accounting standards being tested was matched. From the research results, there was a significant association between SAK as of 1 January 2008 with IFRS as of 1 January 2008.

\section{Research Method}

This study is based on a survey which focuses on accounting professionals' perceptions in Indonesia. The respondents are accountants working in companies and also auditors in the public accounting firms. The survey contains 27 questions on the development and implementation of IFRS to investigate the respondents' perceptions. A closed-questions of 1 to 6 Likert scale is used in this study questionnaire with the score of $6=$ Very Strongly Agree to $1=$ Very Strongly Disagree this scale was used to measure the relative importance and level of agreement of the items. Space was also provided for some open-ended answers.

The total population in this study was 275 accountants and auditors who attended the four accounting events during April and May 2010 in Jakarta held 
The Accountant Perceptions ... by IAI and IAPI (Indonesian Institute of Certified Public Accountant). There was a total sample of 143 respondents (response rate 53.09\%) 76 accountants from companies and 67 auditors from public accounting firms.

Beside the distinction of Audtors or accountants as well as some demographic information, authors are also interested to investigate if foreign affiliation of the institution will provide significant impact toward the positive attitude of the respondents. Considering foreign affiliated firm should have a better knowledge resources from their partners in IFRS adopted countries, accountants work in the foreign affiliated firm should have more opportunities to learn IFRS than accountants in non foreign affiliated firms. Foreign affiliated companies such as multinational companies may also be more prepared for IFRS convergence as they may have their parent or sister company listed in IFRS adopted regions. Thus accountants in foreign affiliated company and auditors in foreign affiliated firms may have a better perception towards IFRS convergence in Indonesia.

\section{Research Questions}

This research would answer the following research questions:

1. Do accountants and auditors possess different perceptions towards IFRS implementation in Indonesia?

2. Do accounting professional's works in the foreign-affiliated institutions possess greater agreement on IFRS implementation than those who are working in a non-affiliated institution?

3. Are there any differences in the perception towards IFRS implementation between accounting professionals of different group based on the years of working experience?

\section{Research Findings}

\subsection{Respondents Demographics}

The percentages of female and male respondents are about equal with 51\% (73) of the respondents are male and 49\% (70) are female. Based on the employability, $53.1 \%$ of the respondents work in public accounting firms (Firm) while the other $46.9 \%$ work in companies (Co).

Based on the working experience, $21.7 \%$ of respondents have 0-5 years working experience, $21 \%$ of the respondents are in the class of 5-10 years working experience and similar percentage for 10-15 years working experience. The majority of the respondent which is $36.4 \%$ have working experience of 15 years and above.

Approximately 50.3\% (72) of the overall respondents had their institutions affiliated with foreign institutions. Meanwhile, 49.7\% (71) of the overall respondents did not have their institutions affiliated with foreign institutions. Furthermore, $55.3 \%$ (42) of the respondents came from the foreign-affiliated Accounting Firm and $44.7 \%$ (34) of the respondents came from the non-affiliated public accounting firms. Additionally, the amount of respondents from foreign-affiliated companies and non-affiliated companies are $30(44.8 \%)$ respondents and $37(55.2 \%)$ respondents respectively.

\subsection{Mean Analysis Based on All Respondents Respond}

The research results on the perceptions of accountants and auditors towards IFRS convergence may be obtained through identifying the mean value on each item in the questionnaire. There were 27 questions provided in the questionnaire to reveal the respondents' level of agreement on factors that affect IFRS convergence in 2012. The questionnaire asked about IFRS implementation's objectives, advantages, challenges, approach and so forth. Moreover, the questionnaire is also designed to assess the perceptions of respondents towards IFRS convergence in Indonesia by 2012 . 
Table 1 described the mean analysis of the respondents' perceptions on the objective of IFRS as single set of global accounting standards. The mean value of 4.63 indicates that all respondents believed that IFRS is 'a worthwhile objective that can be fairly, but gradually accomplished'. In addition, all respondents (with a mean value of 2.85) strongly disagreed that IFRS is 'a highly idealistic objective that is impossible to accomplish'. To prove the significance of mean difference, independent $t$-test was used for this analysis. Referring to table 8 , the p value $(0.000)$ was less than $\boldsymbol{\alpha}=0.05$, which shows that the mean between the two items are significantly different.

\begin{tabular}{lccccc}
\hline Objectives & $\mathbf{N}$ & Mean & $\begin{array}{l}\text { Lev } \\
\text { Sig. }\end{array}$ & $\boldsymbol{p}$-value & $\boldsymbol{\alpha}$ \\
\hline $\begin{array}{l}\text { a) A worthwhile objective that can be fairly } \\
\text { but gradually accomplished }\end{array}$ & 142 & $\mathbf{4 . 6 3}$ & 0.390 & 0.000 & 0.05 \\
$\begin{array}{l}\text { b) A highly idealistic objective that is } \\
\text { impossible to accomplish }\end{array}$ & 135 & $\mathbf{2 . 8 5}$ & & & \\
\hline
\end{tabular}
In my opinion, the objective to achieve a single set of global accounting standards is:

Based on Table 2, the most important advantage of IFRS adoption in Indonesia was to 'achieve greater comparability of financial performance'. This was evident in this table as the value of the mean for item number $2 \mathrm{~A}$, has the highest mean value (4.84). In addition, the lower mean (lower than 4.0) include item number $2 \mathrm{C}$ and $2 \mathrm{D}$ regarding the costs, which states that "the cost of compliance of accounting standards will be reduced considerably" and "IFRS enable to decrease the cost of capital". The reason for this is probably because all of the respondents considered that there would be extra implementation costs needed to adopt IFRS in their institution, for example: training costs. For that reason, the respondents mutually agreed that these two items (2C and $2 \mathrm{D})$ should not be classified as advantages of IFRS adoption in Indonesia. Moreover, the results of this one-way ANOVA analysis showed that the mean value of all five-items are not equal, since the $p$-value $=0.000$ was less than $\boldsymbol{\alpha}=0.01$. Therefore, there were significant mean differences on all the six items.

\begin{tabular}{|c|c|c|c|c|c|}
\hline Advantages & $\mathbf{n}$ & Mean & Lev Sig. & $p$-value & $\alpha$ \\
\hline $\begin{array}{l}\text { a) The standardization of accounting principles } \\
\text { around the world will result in greater } \\
\text { comparability of financial performance }\end{array}$ & 143 & 4.84 & 0.622 & 0.000 & 0.01 \\
\hline $\begin{array}{l}\text { b) Greater relevance, reliability, and transparency } \\
\text { of financial information of companies in } \\
\text { different countries will be achieved }\end{array}$ & 143 & 4.58 & & & \\
\hline $\begin{array}{l}\text { c) The cost of compliance of accounting standards } \\
\text { will be reduced considerably }\end{array}$ & 142 & 3.88 & & & \\
\hline d) Decrease the cost of capital & 140 & 3.81 & & & \\
\hline $\begin{array}{l}\text { e) Facilitate Indonesian companies to enter the } \\
\text { foreign capital markets which are based on } \\
\text { IFRS }\end{array}$ & 143 & 4.83 & & & \\
\hline f) Improve the flow of investment into Indonesia & 143 & 4.44 & & & \\
\hline
\end{tabular}

Table 2 Question 2 In my opinion, the advantage of IFRS adoption in Indonesia is:

Respondents were queried on the challenges of applying IFRS. The mean of all of the items presented in table 3 are above 4.0, which means all respondents agreed on all the statements in table 3 . The table described similar mean value within each item. However, there is a significant mean difference on item number $3 \mathrm{~B}$ and $3 \mathrm{E}$ ( $\mathrm{p}$ value 0.014 was less than $\boldsymbol{\alpha}=0.05$ ). Item $3 \mathrm{~B}$ which states that 'Many fair-value applications in IFRS' were considered as the major challenge in applying IFRS has the highest mean value of 4.48, which was followed by other challenges such as many disclosure requirements and professional judgments.

Fair-value application was considered as the biggest challenge for the accounting professionals, which was probably due to the fact that they have never practiced fair-value application in PSAK before. In contrast, respondents did not have much difficulty to understand the language of PSAK, despite being a translation of IFRS ( Question 3E). Furthermore, one of the challenges in applying IFRS is the need of professional judgments for principle-based accounting. The author initially expected that Question number 3D "Difficult to apply the profe- 
The Accountant Perceptions ...

90

Table 3 Question 3 In my opinion, applying IFRS is not easy because
Table 4 Question 4 In my opinion, the following issues affect accountants in adopting IFRS: ssional judgments in implementing principle-based IFRS" would be the biggest challenge in applying IFRS. Startlingly, the respondents did not show a high level of agreement on this particular item. In addition, the fair-value application was considered as the major challenge, instead of questionnumber 3D about professional judgement....

\begin{tabular}{lccccc}
\hline Challenges & $\mathbf{n}$ & Mean & Lev Sig. & $\boldsymbol{p}$-value & $\boldsymbol{\alpha}$ \\
\hline $\begin{array}{l}\text { a) Different interpretations of IFRSs which may } \\
\text { result in divergence }\end{array}$ & 143 & 4.20 & 0.507 & 0.014 & 0.05 \\
$\begin{array}{l}\text { b) Many fair-value applications } \\
\text { c) Many disclosure requirements that are }\end{array}$ & 143 & 4.48 & & & \\
$\quad \begin{array}{l}\text { required in IFRS } \\
\text { d) Difficult to apply the professional judgments } \\
\text { in implementing principle-based IFRS }\end{array}$ & 143 & 4.35 & 4.27 & \\
$\begin{array}{l}\text { e) Difficult to understand the language of PSAK, } \\
\quad \text { which is the translation of IFRS }\end{array}$ & 141 & 4.16 & & \\
\hline
\end{tabular}

There are 3 issues that affect accounting professionals in adopting IFRS, which include: training of staff to understand and implement IFRS principles, applying institutions' existing quality-control procedures relating to IFRS, and providing IFRS convergence team in institutions as a place to ask questions. The mean of those items were 4.80, 4.38 and 4.09 respectively. Based on the table above, the mean differences were significant within each item as the $p$ value $(0.000)$ was lower than $\alpha=0.05$. Furthermore, all respondents agreed that the training of staffs related to IFRS principles affect them the most, with the highest mean value of 4.80 on item number $4 \mathrm{~A}$. The least affecting issue was on item number $4 \mathrm{~B}$ which was 'the existence of IFRS convergence team in institutions as a place to ask ques' tions is important', with a mean value of 4.09 . The low mean positively suggest that there are still a limited amount of IFRS experts in Indonesian companies and public accounting firms, to guide accountants and auditors to adopt IFRS. This is perhaps one of the factors that cause a slow IFRS implementation in Indonesia.

\begin{tabular}{lccccc}
\hline \multicolumn{1}{c}{ Approaches } & $\mathbf{n}$ & Mean & Lev Sig. & $\boldsymbol{p}$-value & $\boldsymbol{\alpha}$ \\
\hline a) Training of staff to understand and implement & 143 & 4.80 & 0.112 & 0.000 & 0.05 \\
IFRS principles & & & & & \\
b) The existence of IFRS convergence team in \\
$\begin{array}{l}\text { institutions as a place to ask questions is } \\
\text { important }\end{array}$
\end{tabular}

There were three particular professional associations that help in supporting the readiness of accounting professionals towards IFRS convergence by 2012 . They were: IAI, IAPI and governments. Based on table 5, two of the three items had a mean value of below 4.0 which means that the respondents did not think that IAI's and the Government's efforts in supporting accountants and auditors are sufficient. However, item number 5A-IAI efforts and 5B-IAPI efforts reported similar mean values of 3.98 and 4.00 , which are significantly higher than $5 \mathrm{C}$-Government efforts (3.15). As for the significance, the table showed that the $\mathrm{p}$ value (0.000) is lower than $\alpha=0.05$, therefore the items' mean are unequal. The results indicate that IAI and IAPI efforts have been more sufficient in preparing accounting professionals towards IFRS convergence compared to the Governments. The reason for this was most likely because IAI and IAPI are vigorously conducting public hearing, seminar and some training to assess Indonesia's readiness of adopting IFRS by 2012 .

It is also evident from this table, that most respondents preferred item number $6 \mathrm{~A}$ in preparing the general purpose financial statements to public during the 


\begin{tabular}{llcccc}
\hline \multicolumn{1}{c}{ Facilitating Conditions } & $\mathbf{n}$ & Mean & Lev Sig. & $\boldsymbol{p}$-value & $\boldsymbol{\alpha}$ \\
\hline a) $\begin{array}{l}\text { Efforts of IAI (Indonesian Institute of } \\
\text { Accountants) in preparing accountants } \\
\text { towards IFRS convergence has been } \\
\text { sufficient }\end{array}$ & 143 & 3.98 & 0.030 & 0.000 & 0.01 \\
b) Efforts of IAPI (Indonesian Public \\
$\begin{array}{l}\text { Accountants Institute) in preparing public } \\
\text { accountants towards IFRS convergence has } \\
\text { been sufficient }\end{array}$ & 137 & $\mathbf{4 . 0 0}$ & & & \\
c) Efforts of Governments in preparing \\
$\begin{array}{l}\text { accountants towards IFRS convergence has } \\
\text { been sufficient }\end{array}$ & 143 & 3.15 & & & \\
\hline
\end{tabular}

gradual convergence process in Indonesia. The table showed that item number $6 \mathrm{~A}$ 'Companies in Indonesia are allowed to apply early IFRS full-compliance in the reporting year, when capable' has the highest mean value of 4.04. Besides that, the respondents also choose to comply fully with IFRS, by providing reconciliation with PSAK that is applicable at the reporting year. This item, represented by item number $6 \mathrm{~B}$, has a mean value of 3.78 . As shown in the table, the p value $(0.000)$ was smaller than $\boldsymbol{\alpha}=0.05$, which shows inequality with the value of their means. Item number 6C- 'following PSAK only' (3.61) and 6D- 'using SAK non-IFRS' (3.53) have significantly lower mean value compared to item number $6 \mathrm{~A}$ (4.04). It is apparent, that the respondents favored the view of applying early IFRS full compliance during the gradual convergence process, rather than following SAK nonIFRS.

\begin{tabular}{|c|c|c|c|c|c|c|}
\hline & Financial statements & $\mathbf{n}$ & Mean & Lev Sig. & $p$-value & $\alpha$ \\
\hline a) & $\begin{array}{l}\text { Companies in Indonesia are allowed to apply } \\
\text { early IFRS full-compliance in the reporting } \\
\text { year, when capable }\end{array}$ & 143 & 4.04 & 0.851 & 0.000 & 0.05 \\
\hline b) & $\begin{array}{l}\text { Companies in Indonesia are allowed to comply } \\
\text { fully with IFRS, but are required to provide a } \\
\text { reconciliation with PSAK that is applicable at } \\
\text { the reporting year }\end{array}$ & 143 & 3.78 & & & \\
\hline c) & $\begin{array}{l}\text { Companies in Indonesia does not use IFRS, but } \\
\text { still follow PSAK in the reporting year }\end{array}$ & 141 & 3.61 & & & \\
\hline d) & $\begin{array}{l}\text { Companies in Indonesia are allowed to use SAK } \\
\text { non-IFRS, if permitted }\end{array}$ & 140 & 3.53 & & & \\
\hline
\end{tabular}

In Indonesia and other Islamic countries, certain banks and companies follow Islamic conventions of conducting the businesses, such as interest-free banking. As shown in the table above (on Question 7), the respondents were asked on their opinion whether IFRS could be used for this kind of entity. All of the respondents disagreed that IFRS could be used for Islamic entities, demonstrated by a mean value of 3.89. This is probably because respondents thought that Islamic conventions have dissimilar aims and principles with IFRS. Furthermore, all respondents disagreed with the statement in Question 10 which states: 'I worry that IFRS convergence will negatively affect the profitability of companies in Indonesia' (mean value $=3.46$ ). This evidence suggested that all respondents believed IFRS would help to increase the profitability of companies in Indonesia.

\begin{tabular}{lccccc}
\hline \multicolumn{1}{c}{ Other Statements } & & Mean & Lev Sig. & $\boldsymbol{p}$-value & $\boldsymbol{\alpha}$ \\
\hline 8) I believe that Indonesia is ready for IFRS & 142 & 3.86 & 0.416 & 0.004 & 0.05 \\
$\quad \begin{array}{l}\text { convergence by 2012 } \\
\text { 9) I worry Indonesia is not ready for IFRS }\end{array}$ & 140 & 3.51 & & & \\
$\quad \begin{array}{l}\text { convergence in } 2012 \\
\text { 10) I worry that IFRS convergence will negatively } \\
\text { affect the profitability of companies in } \\
\text { Indonesia }\end{array}$ & 168 & 3.46 & - & - & - \\
\hline
\end{tabular}

The respondent's level of agreement on whether Indonesia is ready for IFRS convergence by 2012 were asked on Question 8- 'I believe Indonesia is ready for IFRS convergence' and Question 9 - 'I worry that Indonesia is ready for IFRS
Table 5 Question 5 In my opinion, how does the role of professional associations in supporting the readiness of accounting professionals towards IFRS convergence in 2012 ?

Table 6 Question 6 Indonesia is in the process of gradual IFRS convergence. In the year 2012, PSAK is expected not to be different materially with IFRS as of 1 January 2009. There will still be a gap between PSAK and IFRS. In my opinion, in preparing the general purpose financial statements to public in Indonesia:

Table 7 Question 8-10 Other statements 
The Accountant Perceptions ...

92

Table 8 Significant Mean Difference based on Institution convergence'. Unexpectedly, the mean value of Question 8 (3.86) and Question 9 (3.51) were both below 4.0. Hence, this shows that all of the respondents disagreed with both statements. Moreover, the mean value of both questions were significant, as the $p$ value of 0.004 was higher than $\alpha=0.05$. This means the respondents preferred statement in Question 8 that Indonesia is ready for IFRS convergence by 2012.

\subsection{Accounting Professionals Perceptions Based on Institutions}

\begin{tabular}{lccccc}
\hline & $\begin{array}{c}\text { Accounting } \\
\text { Firm }\end{array}$ & $\begin{array}{c}\text { General } \\
\text { Companies }\end{array}$ & Lev Sig. & $\boldsymbol{p}$-value & $\boldsymbol{\alpha}$ \\
\hline $\begin{array}{l}\text { 2e) Advantage: Facilitate Indonesian } \\
\text { companies to enter the foreign capital } \\
\text { markets which are based on IFRS }\end{array}$ & 4.97 & 4.67 & 0.390 & 0.019 & 0.05 \\
$\begin{array}{l}\text { 3e) Challenge:Difficult to understand the } \\
\text { language of PSAK, which is the }\end{array}$ & 3.95 & $\mathbf{4 . 4 0}$ & 0.015 & 0.002 & 0.05 \\
$\quad \begin{array}{l}\text { translation of IFRS } \\
\text { 4a) Approach:Training of staffs to } \\
\text { understand and implement IFRS } \\
\text { principles }\end{array}$ & 4.62 & $\mathbf{5 . 0 1}$ & 0.292 & 0.005 & 0.05 \\
\hline
\end{tabular}

The result from the independent sample t-test revealed that there are 3 questions that had significant mean differences. Item number $2 \mathrm{E}$ focuses on the advantages of IFRS adoption in Indonesia. Based on the table above, the respondents from $\mathrm{KAP}$ reported a higher level of agreement (significant at 0.05 level) on item $2 \mathrm{E}$ which was 'to facilitate Indonesian companies to enter the foreign capital markets which are based on IFRS'. The author previously expected that respondents from companies would have greater agreement on this item compared to respondents from KAP. Nonetheless, the result showed an opposite outcome where the mean were 4.97 for KAP and 4.67 for companies. This is probably because companies' respondents felt that IFRS would more likely results in a greater comparability of financial performance rather than facilitating Indonesian companies to enter the foreign capital markets. The reason might be because companies' respondents comprehend that it is not easy to enter the foreign capital markets.

In addition, item number $3 \mathrm{E}$ was about the challenges of applying IFRS. Accountants who worked for companies tend to have more problems of understanding the language of PSAK which is a translation of IFRS, as evident in Table 8. Auditors from KAP disagreed with the notion that it is difficult to understand the language of PSAK in applying IFRS, since they reported a mean of 3.95. As it is a one-tailed ttest, the $\mathrm{p}$ value became $0.001(0.002 / 2=0.001)$. The mean between them was significant ( $p$ value one-tailed $0.001<0.05$ ). Hence, it is proven statistically that auditors' mean (3.95) was significantly lower than that of the accountants (4.40).

The result indicated that accountants and auditors have different view on the challenges in applying IFRS. This is possibly because auditors or KAP respondents are more familiar with the language of PSAK as consulting with PSAK was part of their activities in practicing as an auditor. Auditor can, therefore, be expected to have a deeper understanding of accounting standards as compared to accountants. In comparison, accountants from companies consult with PSAK less frequently. 4

The third significant mean difference was on item number $4 \mathrm{~A}$ - 'training to staff to understand and implement IFRS principles' regarding the IFRS approaches. Since its $p$ value (0.005) was lower than $\boldsymbol{\alpha}=0.05$, the mean difference between KAP and companies is significant. Companies' respondents reported a higher mean value of 5.01 on item $4 \mathrm{~A}$ while KAP respondents only reported a mean value of 4.62 . The reason is possibly because there were many staffs in companies that do not have deep accounting background as compared to staffs in KAP. Consequently, respondents from companies believed that training would affect them in adopting IFRS.

\subsection{Accounting Professionals Perceptions Based on Affiliation}

In the questionnaire, the author asked whether the respondent's respective institutions) are affiliated with foreign institution (Multinational Companies or 
Foreign Affiliated Accounting Firms). The data then used to compare the perceptions between the foreign-affiliated group and the non-affiliated group. According to Table 4.1.7, 50.3\% (72) of the respondents came from the foreign-affiliated group; in contrast, $49.7 \%$ (71) of the respondents are from the non-affiliated group. Based on 27 questions on the questionnaire, there are five significant items between the two groups, item number 2A, 3A, Question 8, Question 9 and Question 10.

\begin{tabular}{|c|c|c|c|c|c|}
\hline & $\begin{array}{l}\text { Foreign- } \\
\text { affiliated }\end{array}$ & $\begin{array}{c}\text { Non- } \\
\text { affiliated }\end{array}$ & Lev Sig. & $p$-value & $\alpha$ \\
\hline $\begin{array}{l}\text { 2a) Advantage: The standardization of accounting } \\
\text { principles around the world will result in greater } \\
\text { comparability of financial performance }\end{array}$ & 5.00 & 4.68 & 0.308 & 0.028 & 0.05 \\
\hline $\begin{array}{l}\text { 3a) Challenge: Different interpretations of IFRSs } \\
\text { which may result in divergence }\end{array}$ & 3.97 & 4.42 & 0.612 & 0.002 & 0.05 \\
\hline $\begin{array}{l}\text { 8) Self-efficacy: I believe that Indonesia is ready for } \\
\text { IFRS convergence by } 2012\end{array}$ & 4.06 & 3.66 & 0.053 & 0.019 & 0.05 \\
\hline $\begin{array}{l}\text { 9) Anxiety: I worry Indonesia is not ready for IFRS } \\
\text { convergence in } 2012\end{array}$ & 3.28 & 3.73 & 0.039 & 0.008 & 0.05 \\
\hline $\begin{array}{l}\text { 10) I worry that IFRS convergence will negatively } \\
\text { affect the profitability of companies in Indonesia }\end{array}$ & 3.27 & 3.67 & 0.638 & 0.013 & 0.05 \\
\hline
\end{tabular}

Table 9 examined the results of significant mean value analysis based on foreign-affiliated or non-affiliated groups. Thus, the independent sample t-test was exercised to compare the means of the two groups of variables. It is clear that there was a mean difference between the foreign-affiliated (5.00) and the non-affiliated groups (4.68) on item $2 \mathrm{~A}$, which was the standardization of accounting principles will result in greater comparability of financial performance'. To prove the significance, one-tailed t-test was applied to test that the foreign-affiliated group had a significantly higher mean than the non-affiliated one. The one-tailed $\mathrm{p}$ value of $0.014(0.028 / 2=0.014)$ was lower than significant level of 0.05 , therefore, the mean of foreign-affiliated group was significantly higher.

It can be concluded that the foreign-affiliated group reported a higher level of agreement that IFRS will result in greater comparability of financial performance compared to the non-affiliated group. This possibly occurred because the foreignaffiliated group is used to compare their financial report with its IFRS-based foreign affiliation and foreign competitors. In the meantime, the non-affiliated companies or KAP probably compared their financial performance with domestic competitors that were similarly prepared based on PSAK. Consequently, they did not feel that 'greater comparability of financial performance' is a major advantage of IFRS convergence for the non-affiliated group.

The second mean value difference was on item $3 \mathrm{~A}$ which was about the challenges in adopting IFRS, as exposed in Table 9. The foreign-affiliated group showed a lower mean compared to the non-affiliated group, 3.97 and 4.42 respectively. For the significance test, the one tailed p value $0.001(0.002 / 2=0.001)$ was lower than 0.05 , and thus the mean value of foreign-affiliated group was significantly lower than that of the non-affiliated group. This is possibly because, the non-affiliated group was less likely to adapt and implement IFRS. Therefore, they felt that there would be different interpretations occurred during their first time IFRS adoption. While for the foreign-affiliated group, they would be able to get help from their foreign affiliation for guidance in adapting IFRS.

Referring to table 9, the foreign-affiliated group of respondents reported a higher level of agreement (4.06) on Question 8-'Indonesia's readiness for IFRS convergence in 2012' when compared to the non-affiliated group (3.66). The one-tailed $\mathrm{p}$ value was $0.0095(0.019 / 2=0.0095)$ lower than $\alpha=0.05$, thus the mean differences between both groups were significant. Hence, it can be concluded that the foreignaffiliated group is more confidence that Indonesia is ready for full IFRS convergence in 2012. The reason might be because the foreign-affiliated group could adapt easily with IFRS as they would get the technical supports from their foreign institutions 
The Accountant Perceptions ...

94

Table 10

Significant Mean Difference based on Education

Attainment that had an earlier IFRS adoption. In addition, the foreign-affiliated group recognized IFRS more than its non-affiliated peers.

In addition, there were also other significant mean differences on Question 9 regarding the anxiety towards Indonesia's readiness for IFRS convergence by 2012 . The foreign-affiliated group expressed lower trepidation towards this issue (3.28) compared with the non-affiliated group (3.73). The mean of foreign-affiliated group was significantly lower than the non-affiliated group, where the one-tailed $p$ value $(0.008 / 2=0.004)$ was lower than $\alpha=0.05$. It can be concluded that the nonaffiliated group is concerned that Indonesia may not be ready for IFRS convergence in 2012. Moreover, the non-affiliated group reported a higher mean (3.67) on Question 10 - "I worry that IFRS convergence will negatively affect the profitability of companies in Indonesia". Perhaps, this is due to the fact that the non-affiliated group still has not yet fully grasps the meaning of applying IFRS and how to apply it in their respective companies or KAP.

\subsection{Mean Value Analysis based on Education Attainment}

One of the many ways to compare respondent's perception is using respondent's background of education. One-way analysis of variance was conducted in order to examine the significance of differences between groups for each questionnaire item. The mean value analysis of each group was shown on Appendix B.3. The data were gathered from 4 Diploma-degree respondents, 101 Bachelor-degree respondents, 36 Master-degree respondents, and 2 other degree respondents.

As the sample of Diploma and other-degree respondents was less than 30, the author decided to analyze the mean difference of Bachelor and Master-degree respondents (excluding, Diploma-degree and other degree). From 27 questions asked, there were three items reported with a significant mean difference between groups, as shown in Table 10 below. The levene's significance, the $F$ value and $p$ value of ANOVA, and the alpha significance level were also shown in the table below to prove the mean difference statistically.

\begin{tabular}{|c|c|c|c|c|c|c|c|c|c|}
\hline & \multicolumn{4}{|c|}{ ANOVA } & \multicolumn{4}{|c|}{ Mean Value } & \multirow[b]{2}{*}{ Total } \\
\hline & Lev.sig & $\mathbf{F}$ & sig. & $\alpha$ & Diploma & Bachelor & Master & Others & \\
\hline \multirow{5}{*}{\multicolumn{10}{|c|}{$\begin{array}{l}\text { 4a) IFRS approach: } \\
\text { Training of staff to } \\
\text { understand and } \\
\text { implement IFRS } \\
\text { principles }\end{array}$}} \\
\hline & & & & & & & & & \\
\hline & & & & & & & & & \\
\hline & & & & & & & & & \\
\hline & & & & & & 4.77 & 4.97 & 6.00 & 4.80 \\
\hline \multicolumn{10}{|l|}{ 8) I believe that } \\
\hline \multicolumn{10}{|l|}{ Indonesia is ready for } \\
\hline \multicolumn{10}{|l|}{ IFRS convergence by } \\
\hline 2012 & 0.295 & 7.522 & 0.000 & 0.05 & 3.75 & 3.63 & 4.50 & 4.00 & 3.86 \\
\hline \multicolumn{10}{|l|}{$\begin{array}{l}\text { 9) I worry Indonesia is } \\
\text { not ready for IFRS }\end{array}$} \\
\hline convergence in 2012 & 0.012 & 4.793 & 0.003 & 0.05 & 4.00 & 3.68 & 2.97 & 3.50 & 3.51 \\
\hline
\end{tabular}

As shown in Table 10, there was a significant mean value difference among the four groups on item $4 \mathrm{~A}$, since the $\mathrm{p}$ value $0.001<\alpha=0.05$. Diploma-degree respondents (3.50) and other degree respondents (6.00) have significant mean differences. The table showed that the $p$ value is 0.001 which is lower than $\alpha=0.05$. Since the sample of Diploma-degree and other degree was less than 30, the author decided not to analyze the mean value difference as it would not represent the population.

Referring to Table 10, another significant mean difference among the four education level groups was on Question 8 and 9. In Question 8, the Master-degree group believed that Indonesia is ready for IFRS convergence by 2012 with a level of agreement of 4.50. In contrast, the Bachelor-degree respondents reported a mean value of 3.63 (negative respond). The negative mean value of 3.63 may suggest that they did not believe that Indonesia is ready for IFRS convergence by 2012. Based on the table, it is evident that the mean value of the four groups on Question 8 are not similar as the $p$ value is 0.000 which is lower than $0.05(\boldsymbol{\alpha})$. Consequently, the mean value of Bachelor-degree group and Master-degree group on Question 8 is significant. 
The anxiety level towards Indonesia's readiness for IFRS convergence was also significant between Bachelor-degree respondents and Master-degree respondents, as shown in Table 10 on Question 9. The ANOVA test measured that there was a significant mean difference among the four groups where the $p$ value (0.003) was lower than $\alpha=0.05$. It can be seen that the mean of Bachelor-degree respondents (3.68) was significantly higher than the mean of Master-degree respondents (2.97). In brief, Bachelor-degree respondents are more concerned that Indonesia is not ready for IFRS convergence in 2012 compared to Master-degree respondents. The results of Question 8 and Question 9 suggest that Master-degree respondents have more faith on the readiness of Indonesia for IFRS convergence in 2012 compared to Bachelor-degree respondents. This was probably due to the fact that Master-degree respondents attained more understanding on accounting principles during their study.

\subsection{Accounting Professional Perception Based on Years of Experience}

Despite comparing the mean value of respondent based on the institution, affiliation, and education attainment, the respondents were grouped by their experience level for analysis in this section. The one-way ANOVA was exercised to investigate the significant mean differences among the four groups of variables based on respondent's years of experience.

\begin{tabular}{lcccccccccc}
\hline & \multicolumn{1}{c}{ ANOVA } & \multicolumn{1}{c}{ Mean Value } \\
\cline { 2 - 10 } & Lev.sig & $\mathbf{F}$ & sig. & $\boldsymbol{\alpha}$ & $\mathbf{0 - 5}$ yrs & $\begin{array}{c}\mathbf{5 - 1 0} \\
\text { yrs }\end{array}$ & $\begin{array}{c}\mathbf{1 0 - 1 5} \\
\text { yrs }\end{array}$ & $\begin{array}{c}>\mathbf{1 5} \\
\text { yrs }\end{array}$ & Total \\
\hline $\begin{array}{l}\text { 9) I worry Indonesia is not } \\
\text { ready for IFRS } \\
\text { convergence in 2012 }\end{array}$ & 0.121 & 4.332 & 0.006 & 0.05 & 3.74 & $\mathbf{3 . 9 0}$ & 3.46 & $\mathbf{3 . 1 6}$ & 3.51 \\
\hline
\end{tabular}

Table 11 Significant Mean Difference based on Years of Experience

The mean values reported that the more-experienced respondents showed a higher level of agreement that Indonesia is ready for IFRS convergence in 2012 compared to the less-experienced respondents.

\subsection{Over All Perceptions of Accounting Professionals towards IFRS Con- vergence}

The survey result on accounting professionals' perceptions towards IFRS convergence are obtained from each of the respondent's score from answering the questionnaire. There are a total of 24 questions in the questionnaire, excluding item $6 \mathrm{~B}, 6 \mathrm{C}$ and 7 . Therefore, the minimum score obtained was 24 (minimum score $=$ $24 \times 1$ ) and the maximum was 144 (maximum score $=24 \times 6$ ).

Based on the data analyzed, the total score from the overall respondents were 9,247 , with the average score of 64.66 . Most of the respondents showed a positive perception towards IFRS Implementation in Indonesia. The results reported that $72 \%$ of the respondents have a positive perception, while only $21 \%$ respondents have a negative perception. It can therefore be concluded that, accountants and auditors expressed a positive perspective towards IFRS convergence in Indonesia. From these results, it can be reported that accountants and auditors in Indonesia supported the IFRS convergence plan.

\section{Conclusion, Implication and Limitation.}

Accountants expressed significantly different views from auditors on some issues. Accountants of companies tend to have more problems of understanding the language of PSAK (which is the translation of IFRS) when applying IFRS. Training of staffs to understand and implement IFRS principles was viewed as an important approach for IFRS implementation by both accountants and auditors. However, accountants tend to have greater agreement on this approach. . As there are only three questions out of 27 questions in the survey that result significant difference between these two groups, authors cannot make general conclusion on which group has a better perception toward IFRS Convergence. In conclusion, accountants and auditors possess different perceptions of several IFRS implementation issues. 
The Accountant Perceptions ...
The research may also suggest that the foreign-affiliated group reported a higher level of agreement that IFRS will result in greater comparability of financial performance compared to the non-affiliated group. This is shown by five questions with significant difference between these two group with foreign affiliated group consistently has better score than the non-affiliated group.

Based on education background of the respondents, the Master-degree group believed that Indonesia is ready for IFRS convergence by 2012 with a level of agreement of 4.50. In contrast, the Bachelor-degree respondents reported a mean value of 3.63 (negative respond). The negative mean value of 3.63 may suggest that they did not believe that Indonesia is ready for IFRS convergence by 2012 .

Years of the experience also revealed that the more-experienced respondents showed a higher level of agreement that Indonesia is ready for IFRS convergence in 2012 compared to the less-experienced respondents.

The Implication of this study is to give confidence for Indonesian Institution of Accountants that the convergence process is perceived positively by the accounting professionals. However as Indonesia is on the early stage of convergence process by the time when this research is conducted, the perception of respondents may change closer to the effective year of IFRS implementation which is year 2012 .

\section{References}

Akuntan Indonesia. (2010, January). Konvergensi IFRS. Edisi No.22/Tahun IV/ Januari 2010, p.13.

Armstrong, C., Barth, M. E., Jagolinzer, A.D., \& Reidl, E.J. (2008). Market Reaction to the Adoption of IFRS in Europe. Accounting Review, Forthcoming, Retrieved March 14, 2010, from the Social Science Research Network.

Ball, R. (2006). International Financial Reporting Standards (IFRS): pro and cons for investors. Accounting and Business Research, International Accounting Policy Forum, pp.5-27, 2006, 6.

Cooper. D. R, \& Schindler P. S. (2008). Business Research Methods: Tenth Edition (pp.300-325). McGraw-Hill International Edition.

Daske, H., Hail, L., Leuz, C., \& Verdi, R. (2008). Mandatory IFRS Reporting Around the World: Early Evidence on the Economic Consequences. Social Science Research Network.

Daske, Hail, \& Leuz. (2007). Adopting a Label: Heterogeneity in the Economic Consequences of IFRS Adoptions. Social Science Research Network.

Gassen, J., \& Sellhorn, T. (2006). Applying IFRS in Germany: Determinants and Consequences. Retrieved March 30, 2010, from Social Science Research Network.

Jermakowixz, E. K. (2004). Effects of Adoption of International Financial Reporting Standards in Belgium: The Evidence from BEL-20 Companies. Accounting in Europe, Vol.1.

Joshi, P. L., \& Ramadhan, S. (2002). The adoption of international accounting standards by small and closely held companies.

Jun, Y., \& Koga, C. (2009). Roadmap to Future Mandatory Application of IFRS in Japan: from the Perspective of Financial Statement Preparers.

Marlim, A. V. (2009). Measuring the level of conformity between SAK (Indonesian GAAP) as of 1 January 2008 with IFRS as of 1 January 2008.

Nunnally, J. C. and Bernstein, I. H. (1994). Psychometric Theory. New York: McGrawwHill.

Joshi, P.L.,Bremser, W., \& Al-Ajmi, J. (2008). Perceptions of accounting professionals in the adoption and implementation of a single set of global accounting standards: Evidence from Bahrain. Science Direct, 41-48.

Joshi, P.L, \& Ramadhan, S. (2002). The adoption of international accounting standards by small and closely held companies: Evidence from Bahrain. Science Direct.

Standar Akuntansi Keuangan. (2009). Jakarta: Salemba Empat. 